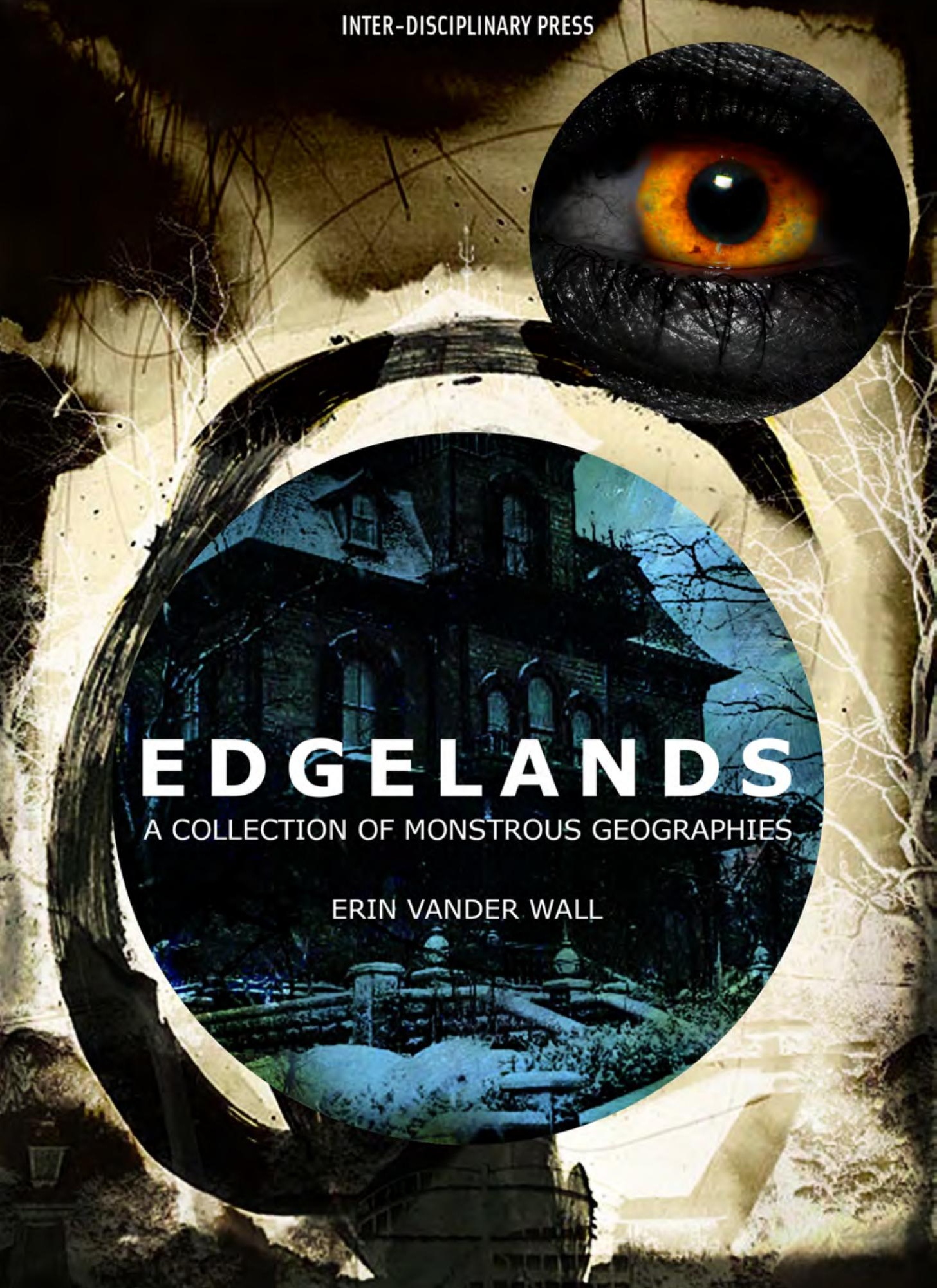




\title{
Citypunk: Transgeographies in Science Fiction Comics
}

\author{
Joao Rosmaninho DS
}

\begin{abstract}
In the history of cyber-fiction in comics there have been bizarre cities with both utopian and dystopian foundations. Mostly located in the future, those urbanscapes are built in space to be recognizable from the present. In fact, they are inevitably linked to variations of our everyday territories. In comics like Dan O'Bannon and Moebius' The Long Tomorrow (1975) or Warren Ellis and Darick Richardson's Transmetropolitan series (1997-2002), cities are characterized and designed as merged environments and inverted punk territories. Urban places become sites of addiction and starvation while technological enterprises continue rising. Mainly set in Europe and North America, the future exposed in these science fiction comics seems rather ungracious and grotesque. Metropolises have grown overscaled and overrated as Paris, London, the generic Cité or The City (a continental compound of New York City, Chicago and San Francisco) have turned into recognizable cities with disturbances and awkward morphologies. Banal places and exquisite architectures become obsolete and opposite versions of themselves. Economic conflicts or politic scandals bring social anarchy and urban-biological ambiguity to these places and their inhabitants. In science fiction comics, protagonists like Pete Club, Alcide Nikopol, Spider Jerusalem or Michael (Desolation) Jones drift through the streets, towers and trash, solving mysteries, testing drugs, and exploring vicious media circles. Paradoxically, these fictions produce a common and complex sense of disenchantment in human and urban promises, as if fiction was just a symbol of our monstrous realities. Mostly based in science fiction comics, this chapter aims at revealing resonances and representations of the contemporary human and urban aberrancies within the graphic genre.
\end{abstract}

Key Words: Science Fiction, Comics, City, Punk, Space, Trans-, Mobility, Media.

\begin{abstract}
$* * * * *$
When there's no future, how can there be sin?

We're the flowers in the dustbin

We're the poison in the human machine

We're the future, we're the future.

Glen Matlock, John Lydon, Steve Jones, and Paul Cook ${ }^{1}$
\end{abstract}

\section{Geographies and Humans}

In science fiction (sf), the city is the place. Often overcrowded and famous for being unfair, the city enhances the battleground to every human revolution. Yet, 
since the Classical polis, social and democratic rights have been addressed in the square, the core of the city, right in the midst of the public realm.

From the 1960's to the 1980's, in Europe and North America, a radical shift of significant civilizational issues happened. Public and private domains got closer while their boundaries became blurred and undistinguished. Matters like security, surveillance, new media, and deregulated markets and corporations fabricated a discriminatory scenario amidst liberalist regimes. Parallel to this arose several counter cultures. From situationism to punk and hippie, a new leftist agenda appeared as a unique alternative to the established and unfair Western world. At the same time, in places like Paris, London, NYC or San Francisco, urban studies researchers were regarding the global and the post-industrial systems through the effects of information networks and worldwide communication. Authors and essayists like Henri Lefebvre, Manuel Castells, and David Harvey were exploring the city as a built subject of capitalist nature. Through fiction based in the future, writers and scholars like Bruce Bethke, Pat Cadigan, William Gibson, Lewis Shiner, John Shirley, Rudy Rucker, Neal Stephenson, or Bruce Sterling were linking political visions to high tech versions of the human. Unprecedented works like Daniel Francis Galouye's Simulacron-3 (1964) alongside Aldous Huxley's reports on drugs and Philip K. Dick's experiments were models to explore. Simulations, artificial intelligence and altered realities became a matter of study and discussion. Indeed, during those same years, through sf comics, artists like Enki Bilal, Warren Ellis, Alejandro Jodorowsky or Jean Giraud 'Moebius' were developing disruptive urban representations as settings for their comics.

Between the late 1970's and early 1980's the political and social sense became even more focused on the city. In literature, themes like structuralism, digital systems, ${ }^{2}$ organic and robotic possibilities, become permanent leitmotivs to every narrative. In sf literature, in both New Wave and Hard Science sub-genres, the optimistic view of technology had been giving way to the deceptive effect of already old technology and, at this point, eugenics had reached its limit while authors like Gibson or Stephenson used their literary and philosophical exercises to form new anxieties, new spaces and new uses. In Ridley Scott's Blade Runner (1982), for instance, the city evolves into a noir fantasy of aerial and ubiquitous commercial screens, quite common in the contemporary Los Angeles (LA) metropolitan area. ${ }^{3}$

A decade later, in the early 1990's, Rem Koolhaas examines metropolises as fragmented and comprehensive geographies all at once. In his $S, M, L, X L$ giant book (1995), the author argues that 'the generic city is the city liberated from the captivity of centre, from the straitjacket of identity. The generic city breaks with the destructive cycle of dependence (...). It is the city without history. ${ }^{4}$ In fact, it seems that Blade Runner's LA is the contemporary architects' dream city. Highly populated and permanently congested, the city became neither tangible nor physical. Its centre got distant to the old one while its form went different from the canonical terms. 


\section{SF Comics and Punks}

In the late 1970's, sf comics were already exploring infinite references. Sprawled morphologies, zoning areas, gated communities, and a particular disregard for human equalities were used to achieve future visions strongly anchored in the existent postmodernity. Moebius and Dan O’Bannon's two-part story The Long Tomorrow (1976) represents an overcrowded and vertically (dis)connected city. Its main character, Pete Club, a Rick Deckard ${ }^{5}$ human prototype, runs indifferently through the levelled environment, solving mysteries and fighting for his own survival. In Cité, the 'generic' name given to the literally underground city, the Cartesian detective calls himself a 'confidential nose', ${ }^{6}$ even if he is dressing like a private eye with a strange fireman hat. In this work, Cité is structured from the powerful and bourgeois top to the poorest bottom. The narrative, as well as the city, is organized between the Earth surface and the 'dump, the [-]199th level', with stops at the [-]97th level, the protagonist's office, and the [-]12th level, the client, Dolly Vook von Katterbar's, home.

The 1980's and 1990's were of great significance to the sf comics sub-genre. Works like Jodorowsky's L'Incal (1981-1989), Toshimichi Suzuki and Tony Takezaki's A.D. Police: Dead End City (1989-1990), Jodorowsky and Juan Giménez's La Cast des Meta-Barons (1992-2003), Howard Chaykin and Don Cameron's Cyberella (1996-1997), or Paul Pope’s Heavy Liquid ${ }^{8}$ series (19992000) have all become graphic and imagetic examples of cyberpunk interpretations. Enki Bilal's La Foire aux Immortels (1980) and La Femme Piège (1986) fictionalize the city between 2023 and 2025 as a place of mixing apparatus and merged atmospheres with humans, gods, aliens and wild animals co-existing in Paris, London and Berlin. European cities are built underground and filled with permanent smog, resembling both familiar and recognizable to current pollution patterns. Each city became helpless despite its futuristic approach.

On the other hand, North-American cities are mainly built upperground and filled with high and low-tech apps. Warren Ellis and Darick Richardson's Transmetropolitan $^{9}$ (1997-2002) and Warren Ellis and J. H. Williams III's Desolation Jones ${ }^{10}$ (2006) claimed then a new visualization for the obsolete near future. In Transmetropolitan, the City is a vast urban sprawl (incorporating New York City, Chicago and San Francisco) crowded with cybernetic organisms. In all these comics, visions of the contemporary city have become as corrupted and toxic as the bodies and political relations humans and gods maintain. ${ }^{11}$

From Europe to America and from Africa to Asia, every city has turned monstrously similar to Blade Runner's urban environment. As Tom Maddox states, 'Cyberpunk had arrived, however you construe the idea. ${ }^{, 2}$ The Long Tomorrow's protagonist Pete Club, La Foire aux Immortels or La Femme Piège's Alcide Nikopol, and Transmetropolitan's Spider Jerusalem fulfill a true commitment with the streets, as all their actions take place there. In fact, Pete, Alcide and Spider are all independent men living as punks do, in the lower parts of the city amidst the dead- 
liest areas. They are contemporary pirates, lonely drifters in crowded places, representing institution-less figures such as those stalked by Joseph Dredd, the complete law enforcement agent in John Wagner and Carlos Ezquerra's Judge Dredd (1977) comic series. As in the fictional Mega City One, ${ }^{13}$ every city is frequently an urban response to fascist or violent scenarios. Protagonists are placed in either political or spatial monstrosities in order to act and react against institutional powers and crooked figures. For instance, Pete and Spider are both activists recording their everyday experiences ${ }^{14}$ and moving through each decadent city to explore its flaws. Pete's places are 'rather disreputable (...) ${ }^{, 15}$ as they are called by Von Katterbar, or 'ratholes ${ }^{\text {,6 }}$ as they are called by Lieutenant 3; Alcide's Earthly awakening happens in decrepit 'Port d'Orleans-Porte de Clignancourt's closed tube station',; ${ }^{17}$ and Spider's urban rejection is written in the streets with the 'I HATE IT HERE' formula, ${ }^{18}$ as he calls to his newspaper New Columns, edited by Mitchell Royce. In fact, the places where they live and circulate are old, dirty, and essentially hostiles to the political authority.

\section{Cities and Hackers}

In the late 70's, New York and London are becoming focal points of the West. In these cities, punk culture emerges as an urban visual routine. Bands like the Ramones in New York City and The Sex Pistols and The Clash in London were the ultimate examples of the punk genre. Ramones (1976), Never Mind the Bollocks, Here's the Sex Pistols (1977), and London Calling (1979) are three musical examples of one culture made by relegated icons and subversive quotes. ${ }^{19}$ Poster collages, pins, piercings, and tattoos make a point alongside the 'do it yourself' culture, as well as graffiti and stencil art. As an example, one could recall Christopher Morris' photographic series NYC subway 1981 (1981) in which the resonances between reality and fiction seem improbable today. The underground built environment full of trash and painted with spray tags turned a new space typology, continuously busy with the indigent and homeless. In effect, in these alternative urbanscapes, characters previously regarded as marginalized crooks turned into central elements.

In the early 1980's, it is not strange that leading anti-heroes come always as outcasts. Software's Cobb Anderson, Neuromancer's Henry Dorsett Case and Molly Millions (aka Sally Shears), or even Snow Crash's Da5id are, actually, anarchists, hackers, and fugitives. Blade Runner's Rick Deckard roams through the neon streets looking for relegated replicants, former 'Off-world (...) slave labour (...), declared illegal on earth, ${ }^{20}$, but ends up caught as one of them.

Between mid 1980's and the 1990's, sf was recreating its own counter culture regarding the representation of 'rebel cities' ${ }^{\text {,1 }}$ and the visions about the genre.

In sf cinema, after Blade Runner, there have been other experiences that relate cyberculture to the digital rise with a punk attitude. Films like Kathryn Bigelow's Strange Days (1995), Robert Longo's Johnny Mnemonic (1995), Abel Ferrara's New Rose Hotel (1998), or the Wachowski brothers' The Matrix (1999) became 
refined examples in which the hacker emerges as an adult character. However, if one includes John Badham's WarGames (1983), James Cameron's Termitator 2: Judgement Day (1991), or Iain Softley's Hackers (1995), it is clear that part of the cast always seems sufficiently young to deal with a computer game turned into a global menace but insufficiently adult to be responsible for it.

In addition, in sf magazines and fanzines, the same genealogy on city and punk is possible. Omni (1979-1998) and Mondo 2000 (1984/1989-1997) ${ }^{22}$ come on as two fine examples, even if their end came simultaneously by the late-1990's following the arrival of Wired (1993), the only global on-going publication dedicated to new technologies and the merging fiction and reality.

\section{Transgeographies and Posthumans}

Since Pico della Mirandola's Oration on the Dignity of Men (1486), monstrosity theme has been connected to Western literature. ${ }^{23}$ In sf terms, one could frame the origin of the mutable nature of human beings somewhere between Mary Shelley's Frankenstein (1818) and Robert Louis Stevenson's Strange Case of Dr. Jekyll and Mr. Hyde (1886). Since then, a (his)story of camouflage and disguise has been explored and further developed with fascinating clues to the body and the city. Expanded and limitless geographies have been linked to amend and degenerate humans. SF comics protagonists like Pete Club, Alcide Nikopol, Spider Jerusalem or Michael Jones deal easily with the boost to their body and mind maintain their social relations and urban territories. Indulgent renegades, they live through the 'filth' ${ }^{24}$ and the fury, as John Lydon ${ }^{25}$ shouts. Captive in their geographies, they are reduced to alien metamorphosis and prosthetic extensions. In La Foire aux Immortels, Horus, an ancient God, uses and abuses Alcide's body in order to rebel himself against the local Parisian fascist government. ${ }^{26}$ In Transmetropolitan, on the other hand, Spider looks alienated from political power. His goggles with round-red and rectangle-green coloured lenses allude to the supposition that politics, reality and geography come all together in more than three dimensions.

Maybe the monstrosity comes in its figurative 'domestication', as left activist and award winning 'weird' fiction author China Miéville argues. There is a 'hegemonic domestication of the dread in humanity and the monstrous ${ }^{, 27}$ and even if it is rather obvious that information and communication have turned to important issues, geographies will maintain their relations with their inhabitants, human or not, widely known or anonymous. 


\section{Notes}

${ }^{1}$ Written by all the Sex Pistols band members. Now, even if the song's lyrics were much related to the originally 'No Future' title, the track did come out to be 'God Save the Queen', due to the Jubilee year.

${ }^{2}$ William J. Mitchell, 'Pulling Glass' in City of Bits (Cambridge: MIT Press, 1996). 2-5

${ }^{3}$ Based in K. Dick's Do Androids Dream of Electric Sheep? (1968), the narrative location was transferred from San Francisco to LA in order to expose a 2019 humid and dark city.

${ }^{4}$ Rem Koolhaas, '7. Guide: the Generic City' in $S, M, L, X L$ edited by Office for Metropolitan Architecture, Rem Koolhaas and Bruce Mau (New York: Monacelli Press, 1995). 1239.

${ }^{5}$ Blade Runner's main character.

${ }^{6}$ Moebius and Dan O’Bannon, 'The Long Tomorrow' in Heavy Metal, Vol. 1, \#4. (Rockville Centre-NY: Metal Mammoth Inc., July 1977). 81.

${ }^{7}$ Ibid. 82.

${ }^{8}$ With its main narrative based in New York City.

${ }^{9}$ It is curious that the title of the series is a compound term: 'trans' is a Latin prefix meaning 'through to, [and] beyond'; and 'metropolitan' is an adjective with Latin and Greek origins (in the word 'metrópolis') meaning 'uterus' and 'city', as the 'mother of all cities'.

${ }^{10}$ With its main narrative based in Los Angeles.

${ }^{11}$ One could yet mention the curious names given to the main genre publishers from that era such as Métal Hurlant magazine and Les Humanoïdes Associés publishing house.

${ }^{12}$ Tom Maddox, 'After the Deluge: Cyberpunk in the '80s and '90s' in Thinking Robots, an Aware Internet, and Cyberpunk Librarians (San Francisco: Library and Information Technology Association, 1992). Viewed 5 May 2014, <http://old.cni.org/pub/LITA/Think/Maddox.html>

${ }^{13}$ The city's name of the Judge Dredd narrative in $2000 \mathrm{AD}$ magazine.

${ }^{14}$ As Pete is a detective and Spider a journalist.

${ }^{15}$ Moebius and Dan O’Bannon, 'The Long Tomorrow' in Heavy Metal, Vol. 1, \#4. (Rockville Centre-NY: Metal Mammoth Inc., July 1977). 82.

${ }^{16}$ Ibid. 84.

${ }^{17}$ Enki Bilal, La Foire aux Immortels (Paris: Les Humanoïdes Associés. 1980). 18

18 Warren Ellis and Darick Robertson, 'Year of the Bastard \#4: Hate' in Transmetropolitan \#3 (New York: DC Comics/Vertigo. 1998-1999). 69.

${ }^{19}$ The first two albums, specifically, were quite short in length $(29 \mathrm{~min}$ and $34 \mathrm{~min}$ respectively) but pretty strong in urban content and ideology. 
${ }^{20}$ Ridley Scott (director), Blade Runner [motion picture] (United States of America: Warner Bros. 1982).

${ }^{21}$ David Harvey. Rebel Cities: From the Right to the City to the Urban Revolution (London/New York City: Verso. 2012).

${ }^{22}$ This one changed its title into Reality Hackers (1988).

${ }^{23}$ Imre Bárd, 'The Doubtful Chances of Choice' in Frontiers of Cyberspace edited by Daniel Riha (Amsterdam: Editions Rodopi B.V., 2012). 5.

Warren Ellis and Darick Robertson, 'Tales of Humans Waste in Transmetropolitan \#0 (New York: DC Comics/Vertigo. 2004). 62.

${ }^{25}$ The Sex Pistols' vox.

${ }^{26}$ Moreover, one may evoke performing artists like Orlan or Stelarc and the work on their own bodies, as it happens to Alcide and his iron right leg implanted.

${ }^{27}$ China Mièville, 'Marxism and Halloween' in Socialism: A Weekend of Radical Debates, Politics and Entertainment (28 June 2013).

\section{Bibliography}

Abbott, Carl. 'Cyberpunk Cities: Science Fiction Meets Urban Theory’ In Journal of Planning Education and Research, \#27, 122-131. November 2007.

Bilal, Enki. La Foire aux Immortels. Paris: Les Humanoïdes Associés. 1980.

---, La Femme Piège. Paris: Dargaud. 1986.

---, Froid Équateur. Paris: Les Humanoïdes Associés. 1992.

Baudrillard, Jean. Simulacros e Simulação, Lisbon: Relógio d’Água, 1991.

De Haven, Tom; and Bruce Jensen. Neuromancer: The Graphic Novel, Vol. 1. Epic Comics. 1989.

Ellis, Warren; and Darick W. Robertson, et. al. Transmetropolitan [series]. New York: DC Comics/Vertigo. 1997-2002.

Erk, Gul Kaçmaz. 'Architectural Space and Cyberspace as Represented in Science Fiction Film’ In OASE, \#66, 6-27. Rotterdam: NAi Publishers, 2005.

Gibson, William. Neuromante, Lisbon: Gradiva, 2004. 
---. 'Disneyland with Death Penalty' In Wired - No1. \#04, London/New York City: Condé Nast Publications, September 2008.

$<$ http://www.wired.com/wired/archive/1.04/gibson_pr.html> Viewed on 23 June 2014.

Haraway, Donna. 'A Cyborg Manifesto: Science, Technology, and SocialistFeminism in the Late Twentieth Century' In Simians, Cyborgs and Women: The Reinvention of Nature. 149-181. New York: Routledge, 1991.

Heuser, Sabine. Virtual Geographies: Cyberpunk at the Intersection of the Postmodern and Science Fiction. Amsterdam/Nova Iorque: Editions Rodopi B.V., 2003.

Lemos, André. 'Ficção Científica Cyberpunk: o Imaginário da Cibercultura' In Conexão - Comunicação e Cultura, Vol. 3, \#6. 9-16. Caxias do Sul: UCS, 2004.

Miller, R. Bruce; and Milton T. Wolf ed. Thinking Robots, an Aware Internet, and Cyberpunk Librarians. San Francisco: Library and Information Technology Association, 1992.

Mitchell, William J.. City of Bits. Cambridge-MA: MIT Press, 1996.

Moebius; and O’Bannon, Dan. 'The Long Tomorrow' In Heavy Metal, Vol. 1, \#4. 80-87. Rockville Centre-NY: Metal Mammoth Inc., July 1977.

---. 'The Long Tomorrow: Part 2' In Heavy Metal, Vol. 1, \#5. 65-72. Rockville Centre-NY: Metal Mammoth Inc., August 1977.

Office for Metropolitan Architecture; Rem Koolhaas; and Bruce Mau. S,M,L,XL. New York: Monacelli Press, 1995.

Riha, Daniel ed. Frontiers of Cyberspace. Amsterdam: Editions Rodopi B.V., 2012.

Scott, Ridley (director). Blade Runner [motion picture]. United States of America: Warner Bros., 1982.

Joao Rosmaninho DS has a BA in Architecture, a MSc in Communication Sciences, and is a PhD student in Architectural Culture. He is faculty staff at the University of Minho. Joao was a visiting fellow at Harvard University in 2013 and a visiting research student at the University College London in 2014. 


\section{EDGELANDS - \\ contectoron}

We are captivated by the monstrous. The monstrous encapsulates a variety of emotions, actions, behaviors, and responses. In general usage it draws attention to the physicality of bodies, the fear and repulsion that have so often driven societal response, and the marginal status of those defined by such terms. Monstrous geographies draw on the unease and uncanniness at the core of the monstrous while shifting the consideration from bodies to places and spaces, away from corporeality and toward the sites or landscapes within which bodies move; away from the monstrous form of a creature like the Yeti and toward the environment in which the Yeti thrives, an environment that must be monstrous to produce and sustain such a being. Considering such geographies allows for a nuanced understanding of the places, both real and imagined, subtle and fantastic, that make up our world.

Erin Vander Wall is with The George Washington University in Washington, D.C. where she works with spatial theory, monster theory, and intersections between the 18th century British novel, the Gothic and the Romantics. She is writing her dissertation on monstrous geographies, focusing specifically on first-hand encounters and literary depictions of earthquakes, volcanoes, storms and quicksand.

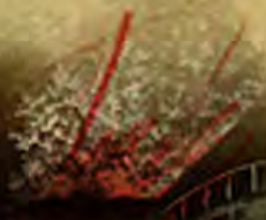

ISBN 978-1-84888-481-6

$£ 7.95$

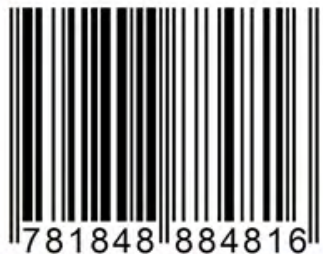

00795 